\title{
Investigation of the Compassion Levels of Faculty of Sports Sciences Students
}

\section{Yahya DOĞAR ${ }^{1}$ Serkan DÜZ ${ }^{2}$}

${ }^{1,2}$ Inonu University, Faculty of Sports Science, Malatya, Turkey. Email:yahya.dogar@inonu.edu.tr Tel: +90422341061s Email.serkanduz@inonuedutr Tel.+90492341115s

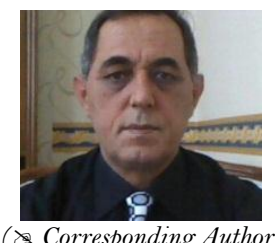

( Corresponding Author)

\begin{abstract}
The aim of this study was to examine the compassion levels of Faculty of Sports Sciences students who study at Inonu University. The sample of the study consisted of 508 students, 191 women and 317 men who voluntarily participated in the study. Compassion Scale (CS) consisting of 24 items and five-point Likert type with six subscales developed by Pommier (2010) and adapted to Turkish by Akdeniz and Deniz (2016) was used to determine the levels of compassion of the students in the study. Independent sample t-test and one-way ANOVA test was used to examine the difference between independent variables and levels of CS. It was found that compassion levels of students were medium. At the end of the study significant differences were found in the indifference and withdrawal subscales according to gender; kindness, indifference, common humanity, separation and disengagement subscales according to the department and kindness, indifference, separation and disengagement subscales according to the income level of families and the exercise habits of the students. There was no significant difference between level of compassion and variable of age and place where the families of students live. As a conclusion, it is useful to examine compassion in various aspects with regard to sports, which is one of the common languages of humanity, with broader and different samples. Thus, it is clear that people who do sports with compassion feelings and thoughts will have positive contributions in reducing violence in sports environments.
\end{abstract}

Keywords: Compassion, Compassionate, Compassion scale, Altruism, Sports, University students.

Citation | Yahya DOĞAR; Serkan DÜZ (2020). Investigation of the Compassion Levels of Faculty of Sports Sciences Students. Asian Journal of Education and Training, 6(2): 267-273.

History:

Received: 27 January 2020

Revised: 9 March 2020

Accepted: 16 April 2020

Published: 14 May 2020

Licensed: This work is licensed under a Creative Commons

Attribution 3.0 License $(\mathrm{cc})$ )

Publisher: Asian Online Journal Publishing Group
Acknowledgement: Both authors contributed to the conception and design of the study.

Funding: This study received no specific financial support.

Competing Interests: The authors declare that they have no conflict of interests.

Transparency: The authors confirm that the manuscript is an honest, accurate, and transparent account of the study was reported; that no vital features of the study have been omitted; and that any discrepancies from the study as planned have been explained.

Ethical: This study follows all ethical practices during writing.

\section{Contents}

1. Introduction

4. Discussion.

References. 


\section{Contribution of this paper to the literature}

This study contributes to the existing literature by examining the compassion levels of the Faculty of Sports Sciences students.

\section{Introduction}

There are values that make people social and live together. All these values, regardless of their content and quality, are human products and continue their existence along with the history of humanity, are subject to many disciplines and are discussed in many fields. However, it seems that his current situation is not very good (Yıldırım, 2016). Since all of the behaviors will be associated with values, it deals with all branches of science from education to economy, from sports to psychology. One of these values is compassion (Deniz \& Karagöl, 2018).

Although compassion is mixed with concepts such as empathy, sympathy, and altruism, its distinctive feature is that it includes a cognitive and behavioral process to relieve pain (Tozoğlu, Dursun, \& Güler, 2019). Compassion is a feeling of sympathy for people or living creatures who are suffering or in a bad condition (Compassion, 2020). While Buddhism defines compassion as an openness to suffering in order to alleviate the suffering of others (Gilbert., McEwan, Matos, \& Rivis, 2011), Islam emphasizes the importance of compassion by using the expression "in the name of Allah, the compassionate, the merciful" (Akın, 2018).

Generally, compassion is an inner feeling that occurs in the individual and can be developed. The sense of compassion occurs when the pain and distress of others are noticed. For this reason, compassion is a benevolent attitude towards all humanity and living things, not only those with whom you are intimately (Avşaroğlu, 2019).

Compassion is the behavior of people who believe that good values and opportunities will increase as they are shared (Goetz, Keltner, \& Simon-Thomas, 2010). Therefore, compassion is actually the desire and attitude of someone else to eliminate the pain. However, the attitude left in feelings and thoughts is not compassion (Avşaroğlu, 2019). Because compassion is an emotion that emerges when witnessing the suffering of others and motivates the desire to help later (Goetz et al., 2010). Therefore, the sense of compassion that increases the value of man and humanity means literally suffering (Stosny, 2004). Ignoring the pain of others causes people to diverge. This is an indication that compassion performs an important unifying function in strengthening the bond between people (Leget \& Olthuis, 2007).

Compassion is in the foundation of all religious thoughts and traditions (Gilbert, 2019). Being compassionate is treating people without prejudice (Avşaroğlu, 2019). In other words, compassion, which includes feelings such as pity, captivity, protection, forgiveness, and showing love and kindness, is the emotion that prompts people to caress an orphan's head, give water to a thirsty dog and leave food to nature so that wild animals do not die in the winter.

As a result of these explanations, it is possible to summarize the compassion as recognizing the pain, understanding the universality of pain in the human experience, feeling empathy for the person suffering and connecting with them, i.e. emotional resonance, ignoring the disturbing behaviors or feelings of the suffering person and accepting them as they are and taking action to alleviate the suffering (Strauss et al., 2016).

It is really difficult for some people to act or talk compassionately. However, it is known that compassionate individuals are more likely to have positive interactions and establish closer relationships with others (Neff, 2003). Because, compassion is a positive and healthy response that involves getting rid of arrogance, anger and revenge that can harm people (Coklar \& Dönmez, 2014). It also protects people against the negative effects of their failures (Akın. \& Akın, 2015). Because compassionate people tend to accept the mistakes of others as they accept that they can also make the mistake (Neff. \& Beretvas, 2013).

Researches mention various positive effects of compassionate behavior. Mongrain, Chin, and Shapira (2011) showed that individuals who act compassionately have higher level of self-esteem, well-being, happiness and low level of depression than those who do not. Moreover, it has been reported that treating patients with compassion, speeding up your recovery process, as well as increasing patient satisfaction (Epstein et al., 2005).

Leary, Tate, Adams, Batts Allen, and Hancock (2007) found that university students with high levels of compassion exhibit more positive and accepting thoughts and behaviors in fulfilling their responsibilities, and show high resistance to problems. Allen and Leary (2010) stated that compassionate people have low levels of aggression and depression, whereas life satisfaction, social connectedness and subjective well-being are high. All these cause individuals to feel emotionally calm and increase their level of welfare (Ryan \& Deci, 2001).

When the literature is analyzed, it is seen that compassion contributes to people's failures in social support, social relations, finding their own personality and extraversion.

It can be said that compassionate individuals approach themselves and their environment more positively and display positive behaviors in their social relationships. This is also true in sports settings. Therefore, it would not be wrong to say that the negative social events occurring especially in sports environments in recent years are due to insufficient understanding of values such as compassion.

Since sports require individuals to compete with each other and to show respect, acceptance and fair play behaviors towards each other, the feeling of compassion is very important. This situation is more important for students who have been studying at sports departments in universities and whose main purpose is to direct people to do sports. Therefore, the aim of this study was to determine the compassion levels of sports science students.

\section{Method}

In this part of the study, the sample of the study, data collection tools and analysis of the data are presented.

\subsection{Research Model}

General screening method was applied in the cross-sectional research design. In the screening method, it is aimed to describe the situation as it exists in the past or currently (Karasar, 2005). 


\subsection{Sample of the Study}

Easy sampling method was used to determine the sample. Easy sampling is a non-random sampling method determined by the researcher's judgments of the sample section chosen from the main group (Hasiloglu, Baran, \& Aydin, 2015). Although the sample size of the research was calculated as at least 383 according to the formula of $\mathrm{Nt}^{2} \mathrm{pq} / \mathrm{d}^{2}(\mathrm{~N}-1)+\mathrm{t}^{2} \mathrm{pq}$ (Sümbüloğlu \& Sümbüloğlu, 2009) with 95\% confidence interval and 5\% sampling error. A total of 632 university students, 191 women and $317 \mathrm{men}$, voluntarily participated in the research from Inonu University faculty of sports sciences. All participants were included in the study in accordance with the principles in the Helsinki Declaration after signing their written informed consent forms. Moreover, ethics committee approval was received from the local university to address ethical concerns.

\subsection{Data Collection Tools}

Compassion Scale (CS) consisting of 24 items five-point Likert type with six subscales developed by Pommier (2010) and adapted to the Turkish by Akdeniz and Deniz (2016) was used to determine the levels of compassion of the students in the study. Cronbach Alpha reliability coefficient of the original scale was determined as 0.85 (Akdeniz \& Deniz, 2016). The scale consists of six sub-dimensions such as kindness, indifference, common humanity, separation, mindfulness and disengagement. Factor loads of items belonging to sub-dimensions vary between .61 and .74 for kindness, .56 and .69 for indifference, .54 and .83 for common humanity, .51 and .73 for separation, .55 and .72 for mindfulness and .58 and .68 for disengagement. The fit indices of the scale were found as $\mathrm{CFI}=.97$; NNFI $=.96 ; \mathrm{SRMR}=.05$ and RMSEA $=.06$. When the internal consistency reliability coefficient is calculated for the sub-dimensions, it is founded as .73 for kindness, .64 for indifference, .66 for common humanity, .67 for separation, .70 for mindfulness, and .60 for disengagement.

The scores of each item vary between " 1 and 5 ". In the scale, each subscale consists of four items and minimum four and maximum 20 points can be obtained from each subscale. Accordingly, the CS is evaluated between 24 and 120 points. As the score rises, the level of compassion increases. It was calculated that cronbach alpha reliability coefficient of this study was 0.74 for the whole scale and ranged between .57 and .77 for the subscales.

\subsection{Data Analysis}

The data were evaluated using the IBM statistics (SPSS version 25.0, Armonk, NY, USA) windows package program. As a result of the Kolmogorov-Smirnov normality test and Skewness and Kurtosis values, the data showed normal distribution. Descriptive statistics were used to determine the demographic characteristics of the participants, independent sample t-test and one-way ANOVA with LSD post-hoc correction were used to examine the differences between the independent variables and CS levels. Statistically significance level was set as p<.05.

\section{Findings}

The findings of the study are explained in detail in the Table 1.

\begin{tabular}{|c|c|c|c|}
\hline Variable & Parameters & f & $\%$ \\
\hline \multirow{2}{*}{ Gender } & Female & 191 & 37.6 \\
\hline & Male & 317 & 62.4 \\
\hline \multirow{3}{*}{ Age (years) } & $17-20$ & 150 & 29.5 \\
\hline & $21-24$ & 314 & 61.8 \\
\hline & $25-40$ & 44 & 8.7 \\
\hline \multirow{4}{*}{ Department } & Physical Education and Sports Teaching & 131 & 25.8 \\
\hline & Coaching Education & 140 & 27.6 \\
\hline & Sports Management & 124 & 24.4 \\
\hline & Exercise and Sports Training for the Disabled & 113 & 22.2 \\
\hline \multirow{3}{*}{ Family Residence } & Village & 71 & 14.0 \\
\hline & District & 149 & 29.3 \\
\hline & City & 288 & 56.7 \\
\hline \multirow{3}{*}{ Monthly Income } & 1-2325 TL (Minimum Wage) & 160 & 31.5 \\
\hline & $2326-4650 \mathrm{TL}$ & 242 & 47.6 \\
\hline & $>4651 \mathrm{TL}$ & 106 & 20.9 \\
\hline \multirow{3}{*}{ Status of doing sports } & No & 136 & 26.8 \\
\hline & Individual & 241 & 47.4 \\
\hline & Team Sports & 131 & 25.8 \\
\hline
\end{tabular}

Note: f: Frequency, \%: Percentage.

Table-2. Relationships between the gender and CS subscales.

\begin{tabular}{|c|c|c|c|c|c|}
\hline Subscales & Gender & $\mathbf{N}$ & $\overline{\mathrm{x}} \pm \mathrm{SD}$ & t-test & $\mathbf{p}$ \\
\hline \multirow[t]{2}{*}{ Kindness } & Female & 191 & $15.88 \pm 3.73$ & \multirow{2}{*}{1.262} & \multirow{2}{*}{.207} \\
\hline & Male & 317 & $15.47 \pm 3.49$ & & \\
\hline \multirow[t]{2}{*}{ Indifference } & Female & 191 & $8.91 \pm 3.70$ & \multirow{2}{*}{-2.411} & \multirow{2}{*}{$.016^{*}$} \\
\hline & Male & 317 & $9.71 \pm 3.57$ & & \\
\hline \multirow[t]{2}{*}{ Common Humanity } & Female & 191 & $14.96 \pm 3.51$ & \multirow{2}{*}{0.096} & \multirow{2}{*}{.924} \\
\hline & Male & 317 & $14.93 \pm 3.29$ & & \\
\hline \multirow[t]{2}{*}{ Separation } & Female & 191 & $9.24 \pm 3.90$ & \multirow{2}{*}{-1.827} & \multirow{2}{*}{.068} \\
\hline & Male & 317 & $9.85 \pm 3.49$ & & \\
\hline \multirow[t]{2}{*}{ Mindfulness } & Female & 191 & $14.93 \pm 3.56$ & \multirow{2}{*}{0.957} & \multirow{2}{*}{.339} \\
\hline & Male & 317 & $14.63 \pm 3.39$ & & \\
\hline \multirow[t]{2}{*}{ Disengagement } & Female & 191 & $8.48 \pm 3.68$ & \multirow{2}{*}{-2.392} & \multirow{2}{*}{$.017^{*}$} \\
\hline & Male & 317 & $9.28 \pm 3.62$ & & \\
\hline
\end{tabular}

Note: ${ }^{*} \mathrm{p}<.05, \mathrm{x} \pm$ SD: mean \pm Standard Deviation. 
According to Table 1, 62.4\% of the participants were male, $37.6 \%$ were female and $61.8 \%$ of students were between 21 and 24 years old. It was seen that $56.7 \%$ of students' families live in the cities, $31.5 \%$ have minimum wage or less, $47.6 \%$ have middle and $20.9 \%$ have high income level. While the rate of students who do not do sports is $26.8 \%$, the rate of those who do individual sports is $47.4 \%$ and that of team sports is $25.8 \%$.

In Table 2, the difference between male and female students was found to be significant according to the indifference and disengagement subscales. It is seen that the difference in indifference and disengagement subscales is in favor of men.

Table-3. Relationships between the age of participants and CS subscales

\begin{tabular}{|c|c|c|c|c|c|}
\hline Subscales & Age & $\mathbf{N}$ & $\bar{x} \pm \mathbf{S D}$ & $\mathbf{F}$ & p \\
\hline \multirow{3}{*}{ Kindness } & $17-20$ & 150 & $15.96 \pm 3.35$ & \multirow{3}{*}{.922} & \multirow{3}{*}{.398} \\
\hline & $21-24$ & 314 & $15.48 \pm 3.69$ & & \\
\hline & $25-40$ & 44 & $15.50 \pm 3.62$ & & \\
\hline \multirow{3}{*}{ Indifference } & $17-20$ & 150 & $9.40 \pm 3.67$ & \multirow{3}{*}{.091} & \multirow{3}{*}{.913} \\
\hline & $21-24$ & 314 & $9.45 \pm 3.66$ & & \\
\hline & $25-40$ & 44 & $9.20 \pm 3.45$ & & \\
\hline \multirow{3}{*}{ Common Humanity } & $17-20$ & 150 & $15.43 \pm 3.18$ & \multirow{3}{*}{2.249} & \multirow{3}{*}{.107} \\
\hline & $21-24$ & 314 & $14.73 \pm 3.45$ & & \\
\hline & $25-40$ & 44 & $14.82 \pm 3.41$ & & \\
\hline \multirow{3}{*}{ Separation } & $17-20$ & 150 & $9.64 \pm 3.47$ & \multirow{3}{*}{1.557} & \multirow{3}{*}{.212} \\
\hline & $21-24$ & 314 & $9.74 \pm 3.74$ & & \\
\hline & $25-40$ & 44 & $8.70 \pm 3.63$ & & \\
\hline \multirow{3}{*}{ Mindfulness } & $17-20$ & 150 & $14.93 \pm 3.22$ & \multirow{3}{*}{.854} & \multirow{3}{*}{.426} \\
\hline & $21-24$ & 314 & $14.74 \pm 3.44$ & & \\
\hline & $25-40$ & 44 & $14.16 \pm 4.26$ & & \\
\hline \multirow{3}{*}{ Disengagement } & $17-20$ & 150 & $9.03 \pm 3.81$ & \multirow{3}{*}{.347} & \multirow{3}{*}{.707} \\
\hline & $21-24$ & 314 & $9.03 \pm 3.63$ & & \\
\hline & $25-40$ & 44 & $8.55 \pm 3.54$ & & \\
\hline
\end{tabular}

Note: * $\mathrm{p}<.05, \overline{\mathrm{x}} \pm \mathrm{SD}:$ mean \pm Standard Deviation.

When Table 3 was examined, it was seen that there was no statistically significant difference between the ages of participants and CS subscales.

Table-4. Relationships between the departments of participants and CS subscales.

\begin{tabular}{|c|c|c|c|c|c|c|c|}
\hline Subscales & Department & $\mathbf{N}$ & $\mathbf{x} \pm$ SD & $\mathbf{F}$ & $\mathbf{p}$ & Group & $\mathbf{p}$ \\
\hline \multirow{4}{*}{ Kindness } & 1) Physical Education Teaching (PE) & 131 & $15.98 \pm 3.58$ & \multirow{4}{*}{2.949} & \multirow{4}{*}{$.032^{*}$} & \multirow{4}{*}{$\begin{array}{l}1>4 \\
3>2 \\
3>4\end{array}$} & \multirow{4}{*}{$\begin{array}{l}.042^{*} \\
.035^{*} \\
.014^{*}\end{array}$} \\
\hline & 2) Coaching Education (CE) & 140 & $15.26 \pm 3.87$ & & & & \\
\hline & 3) Sports Management (SM) & 124 & $16.19 \pm 3.58$ & & & & \\
\hline & 4) Exercise and sport education in disabled (ESED) & 113 & $15.04 \pm 3.13$ & & & & \\
\hline \multirow{4}{*}{ Indifference } & 1) Physical Education Teaching (PE) & 131 & $8.96 \pm 3.42$ & \multirow{4}{*}{9.412} & \multirow{4}{*}{$.000^{*}$} & \multirow{4}{*}{$\begin{array}{l}4>1 \\
2>3 \\
4>2 \\
4>3\end{array}$} & \multirow{4}{*}{$\begin{array}{l}.000^{*} \\
.035^{*} \\
.020^{*} \\
.000^{*}\end{array}$} \\
\hline & 2) Coaching Education (CE) & 140 & $9.70 \pm 4.05$ & & & & \\
\hline & 3) Sports Management (SM) & 124 & $8.396 \pm 3.22$ & & & & \\
\hline & 4) Exercise and sport education in disabled (ESED) & 113 & $10.71 \pm 3.37$ & & & & \\
\hline \multirow{4}{*}{$\begin{array}{l}\text { Common } \\
\text { Humanity }\end{array}$} & 1) Physical Education Teaching (PE) & 131 & $15.49 \pm 3.26$ & \multirow{4}{*}{4.262} & \multirow{4}{*}{$.005^{*}$} & $1>2$ & $.014^{*}$ \\
\hline & 2) Coaching Education (CE) & 140 & $14.49 \pm 3.63$ & & & $1>4$ & $.006^{*}$ \\
\hline & 3) Sports Management (SM) & 124 & $15.45 \pm 3.18$ & & & $3>2$ & $.020^{*}$ \\
\hline & 4) Exercise and sport education in disabled (ESED) & 113 & $14.33 \pm 3.26$ & & & $3>4$ & $.021^{*}$ \\
\hline \multirow{4}{*}{ Separation } & 1) Physical Education Teaching (PE) & 131 & $9.35 \pm 3.40$ & \multirow{4}{*}{10.537} & \multirow{4}{*}{$.000^{*}$} & $4>1$ & $.000^{*}$ \\
\hline & 2) Coaching Education (CE) & 140 & $9.64 \pm 3.76$ & & & $2>3$ & $.012^{*}$ \\
\hline & 3) Sports Management (SM) & 124 & $8.54 \pm 3.47$ & & & $4>2$ & $.013^{*}$ \\
\hline & 4) Exercise and sport education in disabled (ESED) & 113 & $11.10 \pm 3.58$ & & & $4>3$ & $.011^{*}$ \\
\hline \multirow{4}{*}{ Mindfulness } & 1) Physical Education Teaching (PE) & 131 & $14.73 \pm 3.24$ & \multirow{4}{*}{2.199} & \multirow{4}{*}{.087} & & \\
\hline & 2) Coaching Education (CE) & 140 & $14.52 \pm 3.50$ & & & & \\
\hline & 3) Sports Management (SM) & 124 & $15.40 \pm 3.65$ & & & & \\
\hline & 4) Exercise and sport education in disabled (ESED) & 113 & $14.34 \pm 3.36$ & & & & \\
\hline \multirow{4}{*}{ Disengagement } & 1) Physical Education Teaching (PE) & 131 & $8.73 \pm 3.49$ & \multirow{4}{*}{7.172} & \multirow{4}{*}{$.000^{*}$} & $4>1$ & $.002^{*}$ \\
\hline & 2) Coaching Education (CE) & 140 & $9.08 \pm 3.90$ & & & $2>3$ & $.022^{*}$ \\
\hline & 3) Sports Management (SM) & 124 & $8.06 \pm 3.35$ & & & $4>2$ & $.040^{*}$ \\
\hline & 4) Exercise and sport education in disabled (ESED) & 113 & $10.19 \pm 3.62$ & & & $4>3$ & $.000^{*}$ \\
\hline
\end{tabular}

Note: * ${ }^{\mathrm{p}}<.05, \overline{\mathrm{x}} \pm \mathrm{SD}$ : mean \pm Standard Deviation.

When the subscales of CS and the departments of the participants were compared, there was a significant difference in subscales of kindness, Indifference, common humanity, separation and disconnection $(\mathrm{p}<.05)$ except for the mindfulness Table 4. In the kindness subscale, it is seen that the students of PE and SM get higher scores than the students of ESED, and SM students get higher scores than CE students. In the indifference, separation and disengagement subscales, it is seen that ESED students get higher scores than PE and SM students and CE students get higher scores than SM students. In the subscale of common humanity, PE students get higher scores than CE and ESED students, and SM students received higher scores than CE and ESED students. 


\begin{tabular}{|c|c|c|c|c|c|}
\hline Subscale & Place & $\mathbf{N}$ & $\overline{\mathbf{x} \pm \mathbf{S D}}$ & $\mathbf{F}$ & $\mathbf{p}$ \\
\hline \multirow{3}{*}{ Kindness } & Village & 71 & $15.55 \pm 3.71$ & \multirow{3}{*}{.118} & \multirow{3}{*}{.889} \\
\hline & Town & 149 & $15.75 \pm 3.59$ & & \\
\hline & City & 288 & $15.58 \pm 3.57$ & & \\
\hline \multirow{3}{*}{ Indifference } & Village & 71 & $8.72 \pm 3.74$ & \multirow{3}{*}{1.518} & \multirow{3}{*}{.220} \\
\hline & Town & 149 & $9.52 \pm 3.84$ & & \\
\hline & City & 288 & $9.53 \pm 3.50$ & & \\
\hline \multirow{3}{*}{$\begin{array}{l}\text { Common } \\
\text { Humanity }\end{array}$} & Village & 71 & $15.30 \pm 3.56$ & \multirow{3}{*}{.952} & \multirow{3}{*}{.387} \\
\hline & Town & 149 & $15.11 \pm 3.37$ & & \\
\hline & City & 288 & $14.77 \pm 3.34$ & & \\
\hline \multirow{3}{*}{ Separation } & Village & 71 & $8.85 \pm .3 .68$ & \multirow{3}{*}{2.098} & \multirow{3}{*}{.124} \\
\hline & Town & 149 & $9.58 \pm 3.59$ & & \\
\hline & City & 288 & $9.83 \pm 3.67$ & & \\
\hline \multirow{3}{*}{ Mindfulness } & Village & 71 & $14.97 \pm 3.39$ & \multirow{3}{*}{.187} & \multirow{3}{*}{.829} \\
\hline & Town & 149 & $14.75 \pm 3.56$ & & \\
\hline & City & 288 & $14.69 \pm 3.43$ & & \\
\hline \multirow{3}{*}{ Disengagement } & Village & 71 & $8.93 \pm 3.63$ & \multirow{3}{*}{.357} & \multirow{3}{*}{.700} \\
\hline & Town & 149 & $8.79 \pm 3.79$ & & \\
\hline & City & 288 & $9.10 \pm 3.62$ & & \\
\hline
\end{tabular}

According to Table 5, no statistically significant difference was found between the place where the participants grew up and the subscales of CS.

Table-6. Relationships between the monthly income of the participants' family and CS subscales.

\begin{tabular}{|c|c|c|c|c|c|c|c|}
\hline Subscales & Monthly income & $\mathbf{N}$ & $\overline{\mathbf{x} \pm \mathrm{SD}}$ & $\bar{F}$ & $\mathbf{p}$ & Group & $\mathbf{p}$ \\
\hline \multirow{3}{*}{ Kindness } & 1) $1-2325 \mathrm{TL}(\mathrm{low})$ & 160 & $15.64 \pm 3.97$ & \multirow{3}{*}{4.774} & \multirow{3}{*}{$.009^{*}$} & \multirow{3}{*}{$\begin{array}{l}1>3 \\
2>3\end{array}$} & \multirow{3}{*}{$\begin{array}{l}.040^{*} \\
.002^{*}\end{array}$} \\
\hline & 2) 2326-4650 TL (middle) & 242 & $16.00 \pm 2.95$ & & & & \\
\hline & 3) 4651 TL and above (high) & 106 & $14.73 \pm 4.15$ & & & & \\
\hline \multirow{3}{*}{ Indifference } & 1) $1-2325 \mathrm{TL}$ (low) & 160 & $8.58 \pm 3.16$ & \multirow{3}{*}{10.292} & \multirow{3}{*}{$.000^{*}$} & \multirow{3}{*}{$\begin{array}{l}2>1 \\
2>3\end{array}$} & \multirow{3}{*}{$\begin{array}{c}.000^{*} \\
.006\end{array}$} \\
\hline & 2) 2326-4650 TL (middle) & 242 & $10.15 \pm 3.85$ & & & & \\
\hline & 3) $4651 \mathrm{TL}$ and above (high) & 106 & $9.00 \pm 3.52$ & & & & \\
\hline \multirow{3}{*}{ Common Humanity } & 1) $1-2325 \mathrm{TL}$ (low) & 160 & $15.00 \pm 3.53$ & \multirow{3}{*}{1.430} & \multirow{3}{*}{.240} & & \\
\hline & 2) 2326-4650 TL (middle) & 242 & $15.12 \pm 3.15$ & & & & \\
\hline & 3) $4651 \mathrm{TL}$ and above (high) & 106 & $14.46 \pm 3.61$ & & & & \\
\hline \multirow{3}{*}{ Separation } & 1) $1-2325 \mathrm{TL}(\mathrm{low})$ & 160 & $8.71 \pm 3.17$ & \multirow{3}{*}{7.521} & \multirow{3}{*}{$.001^{*}$} & \multirow{3}{*}{$\begin{array}{l}2>1 \\
1>3\end{array}$} & \multirow{3}{*}{$\begin{array}{l}.000^{*} \\
.009^{*}\end{array}$} \\
\hline & 2) 2326-4650 TL (middle) & 242 & $10.10 \pm 3.79$ & & & & \\
\hline & 3) $4651 \mathrm{TL}$ and above (high) & 106 & $9.90 \pm 3.82$ & & & & \\
\hline \multirow{3}{*}{ Mindfulness } & 1) $1-2325$ TL (low) & 160 & $14.66 \pm 3.61$ & \multirow{3}{*}{0.095} & \multirow{3}{*}{.910} & & \\
\hline & 2) 2326-4650 TL (middle) & 242 & $14.81 \pm 3.23$ & & & & \\
\hline & 3) 4651 TL and above (high) & 106 & $14.73 \pm 3.73$ & & & & \\
\hline \multirow{3}{*}{ Disengagement } & 1) 1-2325 TL (low) & 160 & $8.08 \pm 3.24$ & \multirow{3}{*}{10.194} & \multirow{3}{*}{$.000^{*}$} & \multirow{3}{*}{$\begin{array}{l}2>1 \\
2>3\end{array}$} & \multirow{3}{*}{$\begin{array}{l}.000^{*} \\
.018^{*}\end{array}$} \\
\hline & 2) $2326-4650$ TL (middle) & 242 & $9.71 \pm 3.90$ & & & & \\
\hline & 3) 4651 TL and above (high) & 106 & $8.71 \pm 3.43$ & & & & \\
\hline
\end{tabular}

When the relationship between the monthly income level of the participants' families and the subscales of CS was analyzed, significant differences were found in the subscales of kindness, indifference, separation and disengagement. According to the results of post-hoc analysis, the mean score of families with middle income level in kindness, indifference and disengagement subscale was higher than those of low- and high-income levels (Table $6)$.

Table-7. Relationships between the status of doing sports and CS subscales.

\begin{tabular}{|c|c|c|c|c|c|c|c|}
\hline Subscales & Status of doing sports & $\mathbf{N}$ & $\overline{\mathbf{x} \pm \mathbf{S D}}$ & $\mathbf{F}$ & p & Group & $\mathbf{p}$ \\
\hline \multirow{3}{*}{ Kindness } & 1) No & 136 & $16.07 \pm 3.09$ & \multirow{3}{*}{1.874} & \multirow{3}{*}{0.155} & & \\
\hline & 2) Individual & 241 & $15.34 \pm 3.94$ & & & & \\
\hline & 3) Team & 131 & $15.69 \pm 3.35$ & & & & \\
\hline \multirow{3}{*}{ Indifference } & 1) No & 136 & $8.80 \pm 3.31$ & \multirow{3}{*}{6.480} & \multirow{3}{*}{$0.002 *$} & \multirow{3}{*}{$\begin{array}{l}1>3 \\
2>3\end{array}$} & \multirow{3}{*}{$\begin{array}{l}0.001 * \\
0.006^{*}\end{array}$} \\
\hline & 2) Individual & 241 & $9.26 \pm 3.75$ & & & & \\
\hline & 3) Team & 131 & $10.34 \pm 3.60$ & & & & \\
\hline \multirow{3}{*}{$\begin{array}{l}\text { Common } \\
\text { Humanity }\end{array}$} & 1) No & 136 & $15.40 \pm 3.29$ & \multirow{3}{*}{1.837} & \multirow{3}{*}{0.160} & & \\
\hline & 2) Individual & 241 & $14.84 \pm 3.55$ & & & & \\
\hline & 3) Team & 131 & $14.66 \pm 3.12$ & & & & \\
\hline \multirow{3}{*}{ Separation } & 1) No & 136 & $8.93 \pm 3.51$ & \multirow{3}{*}{10.405} & \multirow{3}{*}{$0.000^{*}$} & \multirow{3}{*}{$\begin{array}{l}3>1 \\
3>2\end{array}$} & \multirow{3}{*}{$\begin{array}{l}0.000^{*} \\
0.000^{*}\end{array}$} \\
\hline & 2) Individual & 241 & $9.37 \pm 3.53$ & & & & \\
\hline & 3) Team & 131 & $10.82 \pm 3.79$ & & & & \\
\hline \multirow{3}{*}{ Mindfulness } & 1) No & 136 & $15.35 \pm 3.16$ & \multirow{3}{*}{2.949} & \multirow{3}{*}{0.053} & & \\
\hline & 2) Individual & 241 & $14.46 \pm 3.66$ & & & & \\
\hline & 3) Team & 131 & $14.66 \pm 3.31$ & & & & \\
\hline \multirow{3}{*}{ Disengagement } & 1) No & 136 & $8.29 \pm 3.43$ & \multirow{3}{*}{5.654} & \multirow{3}{*}{$0.004 *$} & \multirow{3}{*}{$\begin{array}{l}3>1 \\
3>2\end{array}$} & \multirow{3}{*}{$\begin{array}{l}0.001 * \\
0.033^{*}\end{array}$} \\
\hline & 2) Individual & 241 & $8.94 \pm 3.72$ & & & & \\
\hline & 3) Team & 131 & $9.79 \pm 3.68$ & & & & \\
\hline
\end{tabular}

Note: $* \mathrm{p}<.05, \overline{\mathrm{x}} \pm \mathrm{SD}:$ mean \pm Standard Deviation.

In Table 7, statistically significant differences were found between the participants' status of doing sports and indifference, separation and disengagement subscales. According to the results of post-hoc analysis, it was observed that those who do not do sports and do individual sports get higher score than those who do sports in the subscale 
of indifference. Moreover, those who do team sports in separation and disengagement subscales get higher score than those do not do sports and do individual sports.

\section{Discussion}

The aim of this study was to determine the compassion level of faculty of sport science students in terms of various variables. At the end of the study, it was found that the mean compassion scores of the participants were at a medium level. Although it is not directly related to the study, there are studies related to the level of compassion. When the literature is analyzed, it is seen that the concept of compassion is not sufficiently included in the book contents or course curricula, therefore, students are not sufficiently informed about compassion (Yiğittir \& Ocal, 2010). It is emphasized that especially teachers do not gain the sense of compassion enough and that the feeling of compassion in children and young people gradually decreases or does not remain (Kıral \& Başdağ, 2017). On the other hand, those who care about social and cultural values such as truthfulness, helpfulness and self-sacrifice are found to be higher than those who do not (Hacıkeleşoğlu \& Kartopu, 2017). This situation may have resulted from both the environmental conditions offered by the university and individual differences related to the individual's willingness to improve himself. Crocker and Canevello (2008) state that compassionate people feel close to others and act supportive, which increases their likelihood of receiving social support from others. So, it would not be wrong to say that compassion improves socialization among people and improves relationships positively. Therefore, people should be able to give up their own right and be humble when necessary. Because personal values can be an obstacle to compassionate life and people. When the results of the study were examined, it was seen that males scored higher than females only in the indifference and disengagement subscales Table 2. In the literature, there are similar and different studies with the results of this study. Beutel and Marini (1995) reported that women scored higher than men in expressing their concerns and responsibilities about the welfare of others, and lower than men in accepting competition. In a study in which the compassion levels of the faculty of education were examined in terms of sports and different variables, it was found that female students get higher scores than males in common humanity and mindfulness subscales, whereas females get lower scores than males in the subscale of indifference (Tozoğlu et al., 2019). In another study, it was seen that male students got higher scores than female students in the subscales of kindness, common humanity and mindfulness (Gülaçtı \& Ciftçi, 2018). Hacıkeleşoğlu and Kartopu (2017) found that women have higher levels of compassion than men. Başer and Tekin (2019) reached the conclusion that kindness, mindfulness and total score of compassion were higher in women, but indifference, separation and disengagement scores were higher in men. The reason for the different results in the studies may be due to the gender of women and their career preferences. It may also have been influenced by the limiting roles of social rules on compassion over men and women. No statistically significant difference was found in all subscales of CS in terms of age variable Table 3. Hacıkeleşoğlu and Kartopu (2017) stated that the tendency to compassion increases with age, while Avşaroğlu. and Güleş (2019) stated that self-compassion of the individuals increases with age. Another study found that the beneficial effects of helping others become evident only among older adults with high social and economic levels (Krause \& Shaw, 2000). The reason for the absence of a significant difference between the level of compassion and the age variable of the students in the study may be due to students not being mature enough to change their compassionate behavior.

When the department variable and the CS subscales were compared, it was found that there was a significant difference in all subscales except the mindfulness subscale (Table 4). In the kindness subscale, PE students got higher scores than ESED students and SM students got higher scores than CE and ESED students. It was observed that ESED students got higher scores than PE and SM students, and CE students got higher scores than SM students in indifference, separation and disengagement subscales. In the common humanity subscale, it was determined that PE students got higher scores than CE and ESED students and SM students got higher scores than CE and ESED students. Tozoğlu et al. (2019) found that the CS scores of the PE students were lower than those of pre-school education students in the subscales of kindness, common humanity and mindfulness, whereas PE students got higher scores in the indifference and separation subscales. However, there was no significant difference in the disengagement subscale. Hacıkeleşoğlu and Kartopu (2017) also found that there was a significant difference between CS scores and department variable in university students, whereas Gülaçtı and Ciftçi (2018) found no significant difference. Therefore, characteristics of the program in departments and that students attend these departments with love and willingly can be effective at the level of compassion of the students.

There was no significant difference in all subscales of CS according to the places where the families of students live Table 5. Especially since the mid-20th century, people's migration to cities, widespread transportation and communication networks, and minimizing cultural differences in rural and urban life can be a factor in the emergence of such a result. A significant difference was found between income of the students' families and kindness, indifference, separation and disengagement subscales Table 6. It was determined that the students with families with middle income level had higher compassion scores than the students with low- and high-income levels in kindness, indifference and disengagement subscales. It is not possible to compare our findings in the literature, since there is no study examining the effect of families' income level on compassion level.

There was a significant difference found between the students' status of doing sports and the mean scores of indifference and separation subscale Table 7 . In the subscale of indifference, it was found that the students who do not do sports got higher scores than those who do team sports and those who do individual sports got higher scores than those who do team sports. In the subscales of separation and disengagement, the scores of the students doing team sports were higher than those who do not do sports and do individual sports. Tozoğlu et al. (2019) reported that students who do sports got higher scores in the indifference subscale than those who do not do sports, while students who do not do sports in mindfulness subscale got higher score than those who do sports. It was observed that the students who do individual sports in the separation subscale have higher scores than those of students who do team sports, and there is no significant difference in the kindness, indifference, common humanity, mindfulness and disengagement subscales. The importance of the fair play concept in sports has been understood better in recent years. The understanding of compassion that covers the concept of fair play makes it important in 
any sports environment. Because concepts such as respect, appreciation and acceptance to the opponent in the fundamental philosophy of sports can be developed with compassion education. Therefore, it is important not to ignore the issue of compassion in all sports institutions and organizations and to add it to routine training programs. As a conclusion, it is useful to examine compassion in various aspects with regard to sports, which is one of the common languages of humanity, with broader and different samples. Thus, it is clear that people who do sports with compassion feelings and thoughts will have positive contributions in reducing violence in sports environments.

\section{References}

Akdeniz, S., \& Deniz, M. (2016). The Turkish adaptation of compassion scale: The validity and reliability study. The Journal of Happiness Well-Being, 4(1), 50-61.

Akın, H. S. (2018). The concept of compassion and the comparison of schopenhauer's approach to compassion with the ideas of other philosophers. Turkish Bioethics Journal, 5(3), 126-131.Available at: https://doi.org/10.5505/tjob.2018.07279.

Akın., A., \& Akın, U. (2015). Investigating predictive role of self-compassion on social self-efficacy. Journal of Educational and Instructional Studies in The World, 5(3), 11-19.

Allen, A. B., \& Leary, M. R. (2010). Self-Compassion, stress, and coping. Social and Personality Psychology Compass, 4(2), $107-118$.

Avşaroğlu, S. (2019). The effect of the compassionate training program on university students' compassionate levels. MANAS Journal of Social Research, 8(3), 2484-2500.Available at: https://doi.org/10.33206/mjss.551706.

Avşaroğlu., S., \& Güleş, E. (2019). Investigation of life satisfaction of the parents who have children with special needs in terms of their compassion and self-understanding levels. Kastamonu Education Journal, 27(1), 365-376.Available at: https://doi.org/10.24106/kefdergi.2960.

Başer, D., \& Tekin, H. H. (2019). Investigation of compassion and altruism levels of social work students (pp. 82-89). Konya: Line Publishing.

Beutel, A. M., \& Marini, M. M. (1995). Gender and values. American Sociological Review, 60(3), 436-448.Available at: https://doi.org/10.2307/2096423.

Coklar, I., \& Dönmez, A. (2014). A review on interpersonal forgiveness. Nesne Journal of Psychology, 2(4), 33-54.Available at: https://doi.org/10.7816/nesne-02-04-03.

Compassion. (2020). In dictionary.cambridge.org dictionary. Retrieved from: https://dictionary.cambridge.org/dictionary/englishturkish/compassion.

Crocker, A., \& Canevello, A. (2008). Creating and undermining social support in communal relationships: The role of compassionate and selfimage goals. Journal of Personality and Social Psychology, 95(3), 555-575 Available at: https://doi.org/10.1037/0022-35 14.95.3.555.

Deniz, K., \& Karagöl, E. (2018). Values in terms of education secondary school Turkish textbooks Karaelmas Journal of Educational Sciences, $6(2), 244-255$.

Epstein, R. M., Franks, P., Shields, C. G., Meldrum, S. C., Miller, K. N., Campbell, T. L., \& Fiscella, K. (2005). Patient-centered communication and diagnostic testing. The Annals of Family Medicine, 3(5), 415-42 1.Available at: https://doi.org/10.1370/afm.348.

Gilbert, P. (2019). Explorations into the nature and function of compassion. Current Opinion in Psychology, 28, 108-114.Available at: https://doi.org/10.1016/j.copsyc.2018.12.002.

Gilbert., P., McEwan, K., Matos, M., \& Rivis, A. (2011). Fears of compassion: Development of three self-report measures. Psychology and Psychotherapy: Theory, research and practice, 84(3), 239-255.Available at: https://doi.org/10.1348/147608310x526511.

Goetz, J. L., Keltner, D., \& Simon-Thomas, E. (2010). Compassion: An evolutionary analysis and empirical review. Psychological Bulletin, 136(3), 351-374.Available at: https://doi.org/10.1037/a0018807.

Gülaçtı, F., \& Ciftçi, Z. (2018). Examination of students' satisfaction, compassion and life satisfaction. In: Dinçer S. (Eds.), Education in a Changing World (pp. 499-506). Ankara: Pagem Publishing.

Hacıkeleşoğlu, H., \& Kartopu, S. (2017). Compassion and religiosity: An empirical research on university students. The Journal of Academic Social Science Studies, 59, 203-227.Available at: https://doi.org/10.9761/jasss7234.

Hasiloglu, B., Baran, T., \& Aydin, O. (2015). Pazarlama arastirmalarindaki potansiyel problemere yonelik bir arastirma: Kolayda ornekleme ve siklik ifadeli olcek maddeleri [A study on the potential problems in marketing research: convenience sampling and scale items with adverbs of frequency]. Pamukkale Journal of Business and Information Management, 2(1), 19-28.

Karasar, N. (2005). Scientific research method. Ankara: Nobel Publishing.

Kıral, B., \& Başdağ, S. (2017). Classroom teachers' opinions about compassion education. Trakya University Journal of Education Faculty, 8(1), 80-96.Available at: https://doi.org/10.24315/trkefd.366689.

Krause, N., \& Shaw, B. A. (2000). Giving social support to others, socioeconomic status, and changes in self-esteem in late life. Journal of Gerontology, 55(6), 323-333.Available at: https://doi.org/10.1093/geronb/55.6.s323.

Leary, M. R., Tate, E. B., Adams, C. E., Batts Allen, A., \& Hancock, J. (2007). Self-compassion and reactions to unpleasant self-relevant events: The implications of treating oneself kindly. Journal of Personality and Social Psychology, 92(5), 887-904.Available at: https://doi.org/10.1037/0022-3514.92.5.887.

Leget, C., \& Olthuis, G. (2007). Compassion as a basis for ethics in medical education. Journal of Medical Ethics, 33(10), 617-620.Available at: https://doi.org/10.1136/jme.2006.017772.

Mongrain, M., Chin, J. M., \& Shapira, L. B. (2011). Practicing compassion increases happiness and self-esteem. Journal of Happiness Studies, 12(6), 963-981.Available at: https://doi.org/10.1007/s10902-010-9239-1.

Neff, K. D. (2003). Self-compassion: An alternative conceptualization of a healthy attitude toward oneself. Self and Identity, 2(2), 85101.Available at: https://doi.org/10.1080/15298860390129863.

Neff., K. D., \& Beretvas, S. N. (2013). The role of self-compassion in romantic relationships. Self and Identity, 12(1), 78-98.Available at: https://doi.org/10.1080/15298868.2011.639548.

Pommier, E. A. (2010). The compassion scale. University of Texas at Austin. Doctorate Thesis. Faculty of the Graduate School: Texas.

Ryan, R. M., \& Deci, E. L. (2001). On happiness and human potentials: A review of research on hedonic and eudaimonic well-being. Annual Review of Psychology, 52(1), 141-166.Available at: https://doi.org/10.1146/annurev.psych.52.1.141.

Stosny, S. (2004). Compassion power: Helping families reach their core value. The Family Journal: Counseling and Therapy for Couples and Families, 12(1), 58-63.Available at: https://doi.org/10.1177/1066480703259041.

Strauss, C., Taylor, B. L., Gu, J., Kuyken, W., Baer, R., Jones, F., \& Cavanagh, K. (2016). What is compassion and how can we measure it? A review of definitions and measures. Clinical Psychology Review, 47, 15-27.Available at: https://doi.org/10.1016/j.cpr.2016.05.004.

Sümbüloğlu, K., \& Sümbüloğlu, V. (2009). Biostatistics. Ankara: Hatipoğlu Publishing.

Tozoğlu, E., Dursun, M., \& Güler, B. (2019). The investigation of compassion levels of education faculty students in terms of sport and different variables. The Journal of Turkish Sport Sciences, 2(2), 156-164.

Yiğittir, S., \& Ocal, A. (2010). Value tendency of 6th grade elementary school students. Selcuk University The Journal of Institute of Social Sciences, 24(1), 407-416.

Yıldırım, D. T. (2016). The importance of values education lesson for gifted children. Current Research in Education, 2(2), 99-120. 